\title{
GAMBARAN BASIL TAHAN ASAM (BTA) POSITIF PADA PENDERITA DIAGNOSA KLINIS TUBERKULOSIS PARU DI RUMAH SAKIT ISLAM SITTI MARYAM MANADO PERIODE JANUARI 2014 S/D JUNI 2014
}

\author{
Velma Buntuan \\ Bagian Mikrobiologi Fakultas Kedokteran Universitas Sam Ratulangi Manado \\ Email: vbuntuan@yahoo.co.id
}

\begin{abstract}
Absract: Tuberculosis is an acute or chronic infectious disease caused by Gram positive bacil, Mycobacterium tuberculosis, which predominantly infect the lungs. The diagnosis of lung tuberculosis in adults is based on the finding of these mycobacyteria in the microscopical examination of sputum. This was a descriptive experimental study to obtain the mycobacteria in patients' sputum stained with Ziehl Neelsen method. Subjects were outpatients and inpatients clinically diagnosed as tuberculosis at the Internal Department of Sitti Maryam Hospital in Manado. The results showed that of 87 samples, there were 48 males (55\%) and 39 females (45\%). Age groups of 0-15 years consisted of 1 sample (1\%); $16-20$ years 0 sample ( $0 \%)$; $21-60$ years 79 samples $(91 \%)$; and $>60$ years 7 samples $(8 \%)$. The microscopical examination showed positive results in 27 samples $(37.0 \%)$ and negative results in 60 samples (69.0\%). Conclusion: Mycobacterium tubercuosis infections were more frequent in males than in females. The most frequent age group was productive age, and the least frequent ages were children and teenagers. The number of positive results of sputum examination for Mycobacterium tuberculosis were less than negative results.
\end{abstract}

Keywords: Mycobacterium tuberculosis, lung tuberculosis.

\begin{abstract}
Abstrak: Tuberkulosis paru adalah penyakit yang menular akut maupun kronis yang terutama menyerang paru, yang disebabkan oleh bakteri tahan asam (BTA) berbentuk batang yang bersifat Gram positif (Mycobacterium tuberculosis). Diagnosis tuberkulosis paru pada dewasa dapat ditegakkan dengan ditemukan BTA pada pemeriksaan mikroskopik dahak. Penelitian ini bersifat deskriptif ekperimental untuk menemukan kuman Mycobacterium tuberculosis pada sputum penderita dengan diagnosa klinis tuberkulosis di Poliklinik dan Rawat Inap Penyakit Dalam RSI Sitti Maryam Manado. Teknik pewarnaan BTA menggunakan metode Ziehl Neelsen. Hasil penelitian memperlihatkan dari 87 sampel, 48 sampel (55\%) berjenis kelamin laki-laki dan 39 sampel (45\%) berjenis kelamin perempuan. Jumlah sampel untuk kelompok usia 0-15 tahun sebesar 1 sampel (1\%); 16-20 tahun 0 sampel (0\%); 21-60 tahun 79 sampel (91\%); dan $>60$ tahun 7 sampel (8\%). Pada pemeriksaan sputum ditemukan BTA pada 27 sampel $(37,0 \%)$ sedangkan pada 60 sampel $(69,0 \%)$ tidak ditemukan. Simpulan: Pengidap tuberkulosis berjenis kelamin laki-laki lebih banyak dari pada perempuan, dengan kelompok usia tersering pada usia produktif dan paling sedikit pada usia anak dan remaja. Pemeriksaan sputum BTA positip lebih sedikit dibandingkan dengan BTA Negatip.
\end{abstract}

Kata kunci: BTA, tuberkulosis paru.

Tuberkulosis adalah penyakit yang menular akut maupun kronis yang terutama menyerang paru, yang disebabkan oleh bakteri tahan asam (BTA) yang bersifat batang gram positif (Mycobacterium tuberculosis). ${ }^{1}$
Epidemiologi sumber infeksi Mycobacterium Tuberculosis yang paling sering ialah manusia yang mengeksresikan basil tuberkel dalam jumlah banyak dari saluran napas. ${ }^{2}$ Di Indonesia, tuberkulosis (TB) masih merupakan masalah besar dan 
merupakan penyebab kematian nomor tiga di dunia setelah Cina dan India. ${ }^{2}$ Multidrug resistance (MDR) TB merupakan penyakit TB yang telah mengalami resistensi terhadap obat isoniazid (INH) dan rifampicin. ${ }^{3}$

Diagnosis TB paru pada dewasa dapat ditegakkan dengan ditemukan BTA pada pemeriksaan dahak secara mikroskopis. ${ }^{4}$

Etiologi TB paru ialah $M$. Tuberculosis yang berbentuk batang. Kuman akan tumbuh optimal pada suhu sekitar $37^{\circ} \mathrm{C}$ dengan $\mathrm{pH}$ optimal 6,4-7. Sebagian besar kuman terdiri atas asam lemak yang menyebabkan kuman lebih tahan asam dan lebih kuat terhadap gangguan kimia dan fisik. ${ }^{5}$

\section{Morfologi dan struktur bakteri}

Morfologi $M$. tuberculosis berbentuk batang halus berukuran panjang 1-4 $\mu$ dan lebar $0,3-0,6 \mu$, pada pembenihan berbentuk kokoid, berfilamen, tidak berspora dan tidak bersimpai. ${ }^{2}$ Kuman ini tahan terhadap asam; etil alcohol 95\% mengandung 3\% asam hidroklorat (asam-alkohol) dengan cepat dapat menghilangkan warna semua bakteri kecuali M. tuberculosis. $^{2}$

Taksonomi dari M. tuberculosis ialah:

$\begin{array}{ll}\text { Kingdom } & \begin{array}{l}\text { Bacteria, } \\ \text { Filum }\end{array} \\ \text { Ordinobacteria, } \\ \text { Actinomycetales, } \\ \text { Sub Ordo } & \begin{array}{l}\text { Corynebacterinea } \\ \text { Famili }\end{array} \\ \begin{array}{l}\text { Mycobacteriaceae, } \\ \text { Genus }\end{array} & \begin{array}{l}\text { Mycobacterium, } \\ \text { Sycobacterium } \\ \text { tuberculosis }\end{array}\end{array}$

Pemeriksaan mikroskopis BTA dari sputum sangat berperan dalam mendiagnosis awal dan pemantauan pengobatan TB paru. ${ }^{7}$ Penelitian ini bertujuan untuk mendapatkan gambaran hasil pemeriksaan BTA pasien dengan diagnosa klinik TB paru di Rumah Islam Sakit Sitti Maryam Manado periode Januari 2014 s/d Juni 2014.

\section{METODE PENELITIAN}

Lokasi Penelitian di Rumah Sakit Islam Sitti Maryam Manado sejak Januari 2014 s/d Juni 2014. Penelitian ini bersifat deskriptif ekperimental dan bertujuan untuk menemukan kuman Mycobacterium tuberculosis pada sputum pasien dengan diagnosis klinis tuberkulosis di Poliklinik dan Rawat Inap Penyakit Dalam RSI Sitti Maryam Manado dan mengunakan pewarnaan BTA dengan Ziehl Neelsen. Variabel dalam penelitian ini ialah pasien dengan diagnosis klinis TB, sputum sewaktu, pagi, dan sesaat (SPS), pemeriksaan BTA, jenis kelamin, dan usia. Pengambilan sampel sputum dilakukan sewaktu, pagi, dan sesaat, dengan pembuatan sediaan dan pewarnaan BTA dengan Ziehl Neelsen. Hasil pemeriksaan berdasarkan standar Internasional Unit Against Tuberculosis (IUAT) (Depkes RI, 2002).

\section{HASIL PENELITIAN}

\section{Distribusi sampel}

Pasien yang memeriksakan diri di poliklinik umum RSI Sitti Maryam Manado mulai bulan Januari 2014 sampai dengan Juni 2014 dengan keluhan batuk lebih dari 2 minggu, panas hilang timbul, keringat malam, nafsu makan menurun dengan diagnosis klinis TB paru sebanyak 87 sampel dilakukan pengambilan sampel sputum 3 kali pengambilan dalam 2 kali kunjungan.

Distribusi sampel berdasarkan jenis kelamin didapatkan dari 87 sampel, 48 sampel $(55 \%)$ berjenis kelamin laki-laki dan 39 sampel (45\%) berjenis kelamin perempuan.

Distribusi sampel berdasarkan kelompok usia menunjukkan bahwa kelompok usia 0-15 tahun sebesar 1 sampel (1\%), 1620 tahun 0 sampel (0\%), 21-60 tahun 79 sampel (91\%), dan $>60$ tahun 7 sampel (8\%).

\section{Hasil pemeriksaan Sputum}

Pemeriksaan sputum BTA yang dilakukan di Laboratorium Mikrobiologi RSI Sitti Maryam Manado terhadap 87 sputum memperlihatkan 27 sampel $(37,0 \%)$ dengan BTA positif dan 60 sampel $(69,0 \%)$ menunjukkan BTA negatif.

\section{BAHASAN}

Penelitian dilakukan pada pasien dengan diagnosis klinis TB paru dari bulan 
Januari sampai dengan Juni 2013 di RSI Sitti Maryam Manado dengan jumlah 87 sampel. Pemeriksaan sampel dengan pengecatan BTA menggunakan metode Ziehl Neelsen. Cara ini sederhana dan mudah dilakukan dengan hasil yang akurat.

Distribusi sampel menurut jenis kelamin menunjukkan bahwa jumlah pasien laki-laki (55\%) dengan diagnosis klinis TB paru lebih banyak dari pada perempuan (45\%). Hasil ini serupa dengan yang dilakukan di Benua Afrika dengan jumlah pasien laki laki $42,34 \%$ dan perempuan $28,9 \%{ }^{8}$ Hal ini antara lain disebabkan karena faktor kebiasaan merokok pada lakilaki yang memudahkan terjangkitnya TB paru. ${ }^{8}$ Kebiasaan merokok akan merusak mekanisme pertahanan paru yang disebut mucociliary clearance. ${ }^{9}$

Distribusi sampel berdasarkan kelompok usia memperlihatkan bahwa yang terbanyak ialah pada usia produktif 20-60 tahun (91\%). Di Indonesia diperkirakan $75 \%$ pengidap TB Paru pada kelompok usia produktif $15-50$ tahun. ${ }^{8}$ Penelitian di Singapura tahun 1987 mendapatkan kelompok usia tersering ialah 15-69 tahun $(73,85 \%)$. Hal ini mungkin disebabkan karena usia produktif banyak bekerja aktif di luar rumah sehingga lebih sering terpapar M. tuberculosis. Penelitian Pertiwi et al. tidak mendapatkan hubungan bermakna antara kejadian TB paru dan kelompok usia 15-55 tahun mempunyai risiko terkena TB Paru dengan risiko 0,667 kali lebih besar dibandingkan umur $>55$ tahun. Hal tersebut dikarenakan ketahanan tubuh mulai menurun setelah umur 45 tahun sehingga rentan terkena penyakit. ${ }^{10}$

Distribusi hasil pemeriksaan BTA penderita dengan hasil positif $\mathrm{Tb}$ Paru pada penelitian ini terdapat 27 sampel $(37,0 \%)$ BTA positip, 60 sampel $(69,0 \%)$ menunjukkan BTA negatip. ini sama dengan hasil penelitian yang dilakukan oleh Susanti D dkk 201250 sampel, positip BTA 23 sampel 46\% sedangan negatip BTA 27 sampel 54\%. Hal Ini kemungkinan karena sampel sputum kebanyakan air liur (saliva) bukan dahak. ${ }^{7}$

\section{SIMPULAN}

Dari hasil penelitian ini dapat disimpulkan pemeriksaan BTA positip pada pasien dengan diagnosis klinis tuberkulosis paru lebih banyak ditemukan pada laki-laki, usia tersering ialah usia produktif, dan hasil pemeriksaan sputum yang BTA positif lebih sedikit daripada BTA negatif.

\section{SARAN}

1. Perlu dilakukan penelitian lanjut dengan melakukan kultur sputum pada penderita tersangka tuberkulosis paru namun hasil pemeriksaan sputum BTA negatif

2. Perlu diperhatikan cara pengambilan sampel sputum yang respresentatif

3. Perlu dilakukan edukasi pada penderita teknik dan cara membatukkan agar yang diperoleh ialah sputum dan bukan saliva.

\section{DAFTAR PUSTAKA}

1. Susanto AD. Analisis Kadar Interferon Gamma Pada Penderita Tuberkulosis Paru dan Orang Sehat. Jurnal Respirologi Indonesia. 2010;30:119.

2. Jawetz, Melnick, Adelberg. Mikobakterium. Dalam: Brooks GF, Butel JS, Morse SA, penyunting. Mikrobiologi Kedokteran (Edisi ke-23). Jakarta: Penerbit Buku Kedokteran FKUI, 2008; h.325.

3. Wahab S. Tuberkulosis. Dalam: Starke JR, penyunting. Nelson Ilmu Kesehatan anak Vol 2 (Edisi ke-15). Jakarta: Penerbit buku kedokteran EGC, 2000; h.1037.

4. Rusnoto, Rahmatullah $\mathrm{P}$, Udiono $\mathrm{A}$, Pemantauan Efektisitas Obat Anti Tuberkulosis Berdasarkan Pemeriksaan Sputum Pada Penderita Tuberkulosis Paru. Jurnal Kesehatan. 2010;3:2.

5. Parhusip MB. Peranan Foto Dada Dalam Mendiagnosis Tuberkulosis Paru Tersangka Dengan Bta Negatif di Puskesmas kodya Medan [disertasi]. Medan: Program Pendidikan Dokter Spesialis 1 Departemen Ilmu Penyakit Paru FK.USU/SMF Paru RSUP. H. Adam Malik Medan; 2009.

6. Widowati H. Tuberkulosis Paru. Dalam: Widowati H, penyunting. Buku Saku Harison Pulmonologi. Tangerang selatan: Karisma Publishing Group, 2012; h.109-10, 119.

7. Regar E. Seminar diagnosis tuberkulosis. Laboratorium Pulmonologi FK UI, 2012. 
596 Jurnal e-Biomedik (eBM), Volume 2, Nomor 2, Juli 2014, hlm. 593-596

8. SuarniH,http://lib.ui.ac.id/file?file=digital/12 5833-S-5761-Faktor\%20risiko-

Literatur.pdfRab T. Ilmu penyakit paru. Jakarta: Trans info media; 2010. h. 163-64.

9. Tirtana BT, Musrichan. Faktor-Faktor Yang Mempengaruhi Keberhasilan Pengobatan Pada Pasien Tuberkulosis Paru Dengan Resistensi Obat Anti Tuberkulosis di Wilayah Jawa Tengah [disertasi]. Jawa
Tengah: Fakultas Kedokteran Universitas di Ponegoro; 2011. h. 4.

10.Tirtana BT, Musrichan. Faktor-Faktor Yang Mempengaruhi Keberhasilan Pengobatan Pada Pasien Tuberkulosis Paru Dengan Resistensi Obat Anti Tuberkulosis di Wilayah Jawa Tengah [disertasi]. Jawa Tengah: Fakultas Kedokteran Universitas di Ponegoro; 2011; h.4. 